\title{
EFFICIENCY ANALYSIS OF FINANCIAL MANAGEMENT ADMINISTRATION OF ABC HOSPITAL USING FINANCIAL RATIO ANALYSIS METHOD
}

\author{
Jonny \\ Accounting Department, Faculty of Economic and Communication, Bina Nusantara University, \\ Jln. K.H. Syahdan No 9, Jakarta Barat, DKI Jakarta, 11480, Indonesia \\ jonny@binus.ac.id
}

Received: $26^{\text {th }}$ June 2015/ Revised: $11^{\text {th }}$ September 2015/ Accepted: $14^{\text {th }}$ January 2016

How to Cite: Jonny. (2016). Efficiency Analysis of Financial Management Administration of ABC Hospital

Using Financial Ratio Analysis Method. Binus Business Review, 7(1), 65-69. http://dx.doi.org/10.21512/bbr.v7i1.1456

\begin{abstract}
Article evaluated the financial performance of ABC hospital within the period of 2012 to 2013 to overcome the problems related to how to measure and present its financial performance using ratio analysis. These financial ratios were employed to measure the liquidity, assets utilization, long-term solvency and profitability of the hospital. This analysis was conducted in order to prove whether the hospital has been managed efficiently or not in accordance to Indonesian Hospital Quality Accreditation as stated in its clause on Administration Standard No. 5 Parameter No. 3 that the hospital financial management shall be conducted in appropriate way in order to guarantee its operation efficiently. The result show that overall financial performance of ABC hospital increase considerably in those two years. A significant change is occurred on its solvency ratio which is decreased from $-2 \%$ to $-8 \%$, indicating its loose dependency due to its founder's strong financial support. Therefore, based on this favorable result, the hospital is regarded to have efficient hospital management and thus, together with other standard fulfillment, it is accredited by Indonesian Health Ministry.
\end{abstract}

Keywords: efficiency analysis, financial ratio, liquidity ratio, assets utilization ratio, long-term solvency ratio, profitability ratio

\section{INTRODUCTION}

In Indonesia, the number of hospitals is growing tremendously in these recent years. Despite of this growing number of Indonesian hospitals, the number of Indonesian patients going aboard in order to get better quality of healthcare treatment is also growing rapidly. This condition can be considered as ironic especially it happens in the middle of the Indonesian government's efforts in suppressing this growing number of Indonesia patients having medical treatments aboard due to its potency of losing foreign exchange reserves. Having observed this condition, the government has taken several initiatives in order to prevent Indonesian patients going aboard for having medical treatments there. One of those initiatives is related to quality improvement by enforcing nationwide policy in order to ensure all Indonesian hospitals to grant Indonesian healthcare accreditation. This accreditation is a strong evidence that the government has recognized the healthcare quality for the subjected hospital. This enforcement has been legally regulated through the establishment of Indonesian healthcare law No. 44 in the year 2009. This law has enforced that every hospital must grant Indonesian healthcare accreditation from the appointed Indonesian Healthcare Accreditation Commission in order to be granted hospital's operational permission. By having this law, Indonesian government hopes that the quality of Indonesian hospitals could not only be improved but also continually monitored by Indonesian Health Ministry. Therefore, the Indonesian patients do not need to go abroad for having good medical treatments there so that the potency of losing foreign exchange 
reserves can be prevented because the patients could get the quality of healthcare at home that is equal to the quality of foreign hospital aboard. Furthermore, by having this law, it can also help and prepare domestic hospital in order to face the fierce competition era during the upcoming ASEAN free-trade agreement in 2015.

Regarding to the healthcare accreditation program, the government has issued hospital quality standard that every hospital shall fulfill in order to be granted with its accreditation certificate. This standard is issued by Indonesian Healthcare Accreditation Commission in the year of 2007 in which its content is adopted from International Society for Quality in Healthcare with its headquarter in Dublin, Ireland. Later, this standard is known as Accreditation version 2007. Based on this standard, every hospital has to prove its capability to fulfill every standard and parameter listed as its requirements in order to be granted accreditation certificate as pre-requisite to be granted or extend the hospital's operational permit from the government. This is done by independent assessor appointed by Indonesian Healthcare Accreditation Commission in order to prove whether the hospital has fulfilled the requirements or not.

According to Indonesian Healthcare Accreditation (2011), the government has issued healthcare quality standard that should be fulfilled consisting of 5 services, 12 services and 16 services which can be chosen by the subjected hospital based on its size. ABC hospital is registered as hospital performing 5 services. In more details, these 5 services which are required to be accredited by the government consists of administrative, medical, emergency, nursing and medical recording services. Every service of these 5 services shall fulfill its respective quality service standards in which its each standard has 7 parameters regulating on how hospital can fulfill the required standard including philosophy and purposes, administration and management, facility and equipment, policy and procedure, staff development and education program and evaluation and quality control.

This research is aimed to analyze on whether the hospital's financial management has been performed well or not so that it can fulfill the standard of administrative service standard stated in Standard 5 about policy and procedure as well as parameter 3 to guarantee that in order to prove that the hospital's management is able to perform good operational service then the management should perfume financial ratio analysis documents from the accreditation subjected hospital. Therefore, in order to prepare this document, this research is conducted to provide a big and factual picture about the financial performance of $\mathrm{ABC}$ hospital using financial ratio analysis so that objective comparison can be done for the consecutive years of 2012 and 2013 as analytical period basis.

\section{METHODS}

According to Haka (2010), in order to provide a document of financial ratio analysis in holistic ways as required by Indonesian Healthcare Accreditation, the most appropriate method to be used is financial ratio analysis on the hospital's financial statement issued by the management of $\mathrm{ABC}$ hospital for the year 2013 and 2013 covering liquidity ratio, asset utilization ratio, long-term solvency ratio and profitability ratio. Meanwhile, market ratio is excluded because ABC hospital is considered as private company and not public company. The following section is to describe in more detail related to the four classifications of financial analysis ratio (Florenz, 2012).

Current Ratio, a part of liquidity ratio, is used to measure whether the hospital can meet its obligation as stated in current liabilities using its current assets by using the following formula:

$$
\text { Current Ratio }=\frac{\text { Total Current Assets }}{\text { Total Current Liabilities }}
$$

Quick (Acid Test) Ratio, also a part of liquidity ratio, is used to show the ability of the hospital to pay its liabilities in fast manner by using the following formula:

$$
\underset{\text { Ratio }=}{\text { Quick (Acid Test) }} \frac{\text { Current Asset }- \text { Inventories }}{\text { Current Liabilities }}
$$

Cash Ratio, as covered by liquidity ratio, is used to prove the ability of the hospital using cash or marketable securities if any to cover its current liabilities by applying the following formula:

$$
\text { Cash Ratio }=\frac{\text { Cash }+ \text { Marketable Securities }}{\text { Current Liabilities }}
$$

Inventory Turnover Ratio, as part of assets utilization ratio, is a ratio to evaluate on how fast the hospital sells, uses and manages its medical inventories using the following formula:

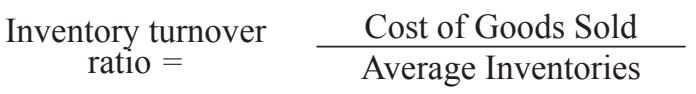

Day's Inventory, as stated from assets utilization ratio, is used to show that lower day's inventory may indicates higher cost relative to the hospital's revenue by deploying the following formula:

$$
\text { Day’s Inventory }=\frac{365}{\text { Inventory Turnover }}
$$

Account Receivables (AR) Turnover Ratio, as part of assets utilization ratio, is the most common ratio used by hospital to measure how fast the hospital can collect its bills from patients using credit as payment method by using the following formula: 


$$
\text { AR turnover ratio }=\frac{\text { Sales }}{\text { Average Receivables }}
$$

Day's Receivable, also as part of assets utilization ratio, is a measure to indicate how long it takes to collect hospital's receivable and turn it into cash for the hospital operational needs by deploying the following formula:

$$
\text { Day's receivable }=\frac{365}{\text { Receivables Turnover }}
$$

Total Debt Ratio, as part of long-term solvency ratio, is used to measure how dependence of the hospital on its debt by applying the following formula:

$$
\text { Total debt ratio }=\frac{\text { Total Debt }}{\text { Total Assets }}
$$

Debt to Equity Ratio, as covered from longterm solvency ratio, is used to show margin of safety of the hospital on its creditor by using the following formula:

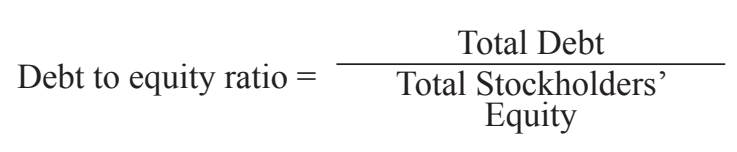

Return on Assets, as part of profitability ratio, is a ratio used to show how the hospital has use its all resources in order to achieve its revenue by deploying the following formula:

$$
\text { Return on Assets }=\frac{\text { Net Income }}{\text { Average Total Assets }}
$$

Return on Equity, as covered by profitability ratio, is used to calculate how much money the hospital has earned benefiting from investor's funds by using the following formula:

$$
\text { Return on Equity }=\frac{\text { Net Income }}{\underset{\text { Average Shareholders' }}{\text { Equity }}}
$$

Those four classifications of financial ratio analysis as described above are commonly used by hospital to measure how efficient the hospital has managed (Garrisson, 2012). The results of these measures will be further compared to the minimum standard as stated by the government from its issued minimum service standard through the Indonesian ministry of health.

\section{RESULTS AND DISCUSSIONS}

According to the selected methodology as described on previous section, the following section is the result and discussion made based on its financial statements issued on 2012 and 2013 which have been created, evaluated, and audited by independent monitoring units form by the hospital as pre-requisite to state that the document is legal or not. For more details on the results of the document stating the financial ratio measures as the evidence that the financial management of the hospital has been performance accordingly to the government's requirement are presented in Table 1.

Table 1 Balance Sheet of ABC Hospital period $2012-2013$

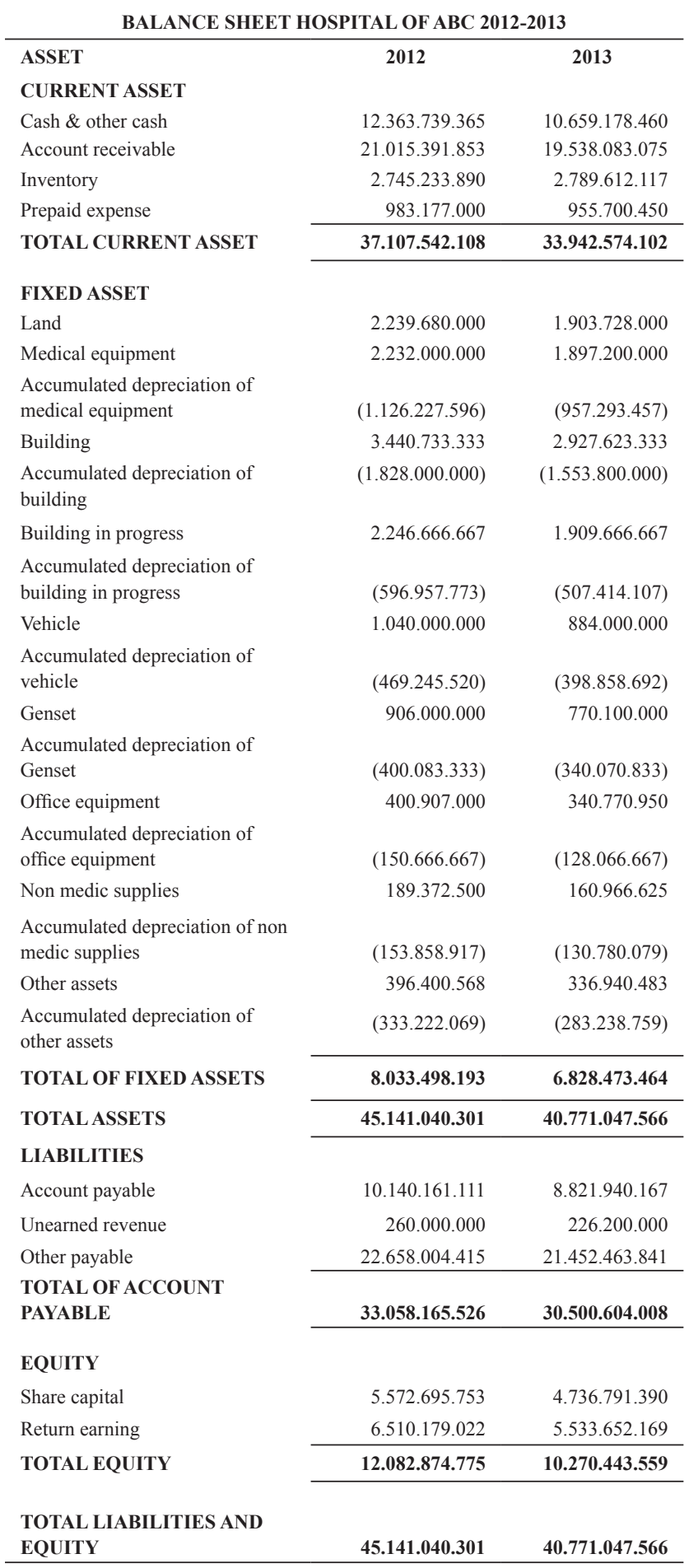


Table 2 shows the income statement of $\mathrm{ABC}$ Hospital period of 2012 and 2013:

Table 2 Income Statement of ABC Hospital period of 2012 - 2013

\section{INCOME STATEMENT ABC HOSPITAL 2012-2013}

\begin{tabular}{l}
\hline REVENUE \\
I. OPERATIONAL REVEN \\
Revenue of inpatient \\
Revenue of outpatient \\
Revenue of diagnosis supp \\
II. OTHER REVENUE \\
Revenue of pharmacy \\
Revenue of medical tool \\
Other revenue
\end{tabular}

2013

2012

\section{OPERATIONAL REVENUE}

$\begin{array}{rr}21.616 .244 .594 & 18.373 .807 .905 \\ 7.317 .794 .300 & 6.220 .125 .155 \\ 8.945 .092 .324 & 7.603 .328 .475\end{array}$

TOTAL REVENUE

$28.061 .407 .338 \quad 23.852 .196 .267$

2.004.466.657 1.703 .796 .658

$58.500 .000 \quad 49.725 .000$

$68.003 .505 .213 \quad 57.802 .979 .431$

\section{B. OPERATIONAL EXPERIENCE}

\section{SERVICE EXPENSE}

$\begin{array}{lrr}\text { Inpatient expense } & 12.889 .070 .768 & 10.955 .710 .153 \\ \text { Outpatient expense } & 9.263 .125 .470 & 7.873 .656 .650 \\ \text { Medical equipment } & 6.261 .564 .627 & 5.322 .329 .933 \\ \text { Doctor wages } & 23.147 .231 .115 & 19.675 .146 .448 \\ \text { Medical tool } & 1.603 .573 .326 & 1.363 .037 .327\end{array}$

\section{GENERAL AND ADMINISTRATIVE EXPENSE}

Owner wages

Travelling expense

Depreciation expense

Fuel expense

Parking \& toll expense

Vehicle maintenance expense

Office supplies

Advertising

Electricity, gas \& water

Telephone \& internet expense

Retribution expense

Marketing expense

$$
\begin{array}{rr}
4.076 .316 .023 & 3.464 .868 .620 \\
506.608 .705 & 430.617 .399 \\
98.500 .000 & 83.725 .000 \\
976.400 .958 & 829.940 .814 \\
91.049 .500 & 77.392 .075 \\
20.583 .000 & 17.495 .550 \\
48.960 .000 & 41.616 .000 \\
134.890 .100 & 114.656 .585 \\
75.000 .000 & 63.750 .000 \\
878.107 .352 & 746.391 .249 \\
82.833 .364 & 70.408 .359 \\
29.368 .308 & 24.978 .362 \\
80.100 .000 & 68.085 .000
\end{array}
$$

\section{OTHER EXPENSE}

Medical equipment

maintenance expense

Environment maintenance

expense

\section{TOTAL EXPENSE \\ INCOME BEFORE TAX \\ INCOME TAX \\ NETT INCOME}

\begin{tabular}{rr}
250.000 .000 & 212.500 .000 \\
& \\
50.000 .000 & 42.500 .000 \\
& \\
\hline $\mathbf{6 0 . 5 6 3 . 3 0 0 . 6 1 6}$ & $\mathbf{5 1 . 4 7 8 . 8 0 5 . 5 2 4}$ \\
\hline $\mathbf{7 . 4 4 0 . 2 0 4 . 5 9 7}$ & $\mathbf{6 . 3 2 4 . 1 7 3 . 9 0 7}$ \\
\hline 930.025 .575 & 790.521 .738 \\
\hline $\mathbf{6 . 5 1 0 . 1 7 9 . 0 2 2}$ & $\mathbf{5 . 5 3 3 . 6 5 2 . 1 6 9}$ \\
\hline
\end{tabular}

For details on the results of its financial ratio analysis, the following section is specially created to present the need. Table 3 presents the calculation result after deploying the financial ratio for classification of liquidity ratio as depicted in the Table 3.

Table 3 Liquidity Ratio

\begin{tabular}{lcccc}
\hline \multicolumn{1}{c}{ Ratio } & $\mathbf{2 0 1 3}$ & $\mathbf{2 0 1 2}$ & $\begin{array}{c}\text { \% Increase } \\
\text { (Decrease) }\end{array}$ & Remark \\
\hline Current Ratio & 1,12 & 1,11 & $1 \%$ & $\mathrm{Up}$ \\
Acid Test Ratio & 1,04 & 1,02 & $2 \%$ & $\mathrm{Up}$ \\
Cash Ratio & 0,37 & 0,35 & $7 \%$ & $\mathrm{Up}$ \\
\hline
\end{tabular}

Table 3 shows that the current ratio of the hospital has increased from 1.11 to 1.12 or up $1 \%$. This result shows that its ability to pay its current liabilities has undergone increase and can be considered healthier. For acid test ratio, from table 1, it stated that the acid test ratio has also increased from 1.02 to 1.04 or up $2 \%$. This results also show favorable one that its ability to cover its current liabilities without scarifying its inventories. Of course, this result has strengthened its perspective of good financial management. From the same table, its cash ratio shows a great result which increases from 0.35 to 0.37 . However, because its result is under 1.00 then it can be stated that its ability to cover its current liability using cash is still weak. That is why the owner of the hospital keeps investing funds in order to cover its immediate obligation.

Table 4 is the summary of financial ratio calculation for the classification of the asset utilization ratio.

Table 4 Asset Utilization Ratio

\begin{tabular}{lcccc}
\hline \multicolumn{1}{c}{ Ratio } & $\mathbf{2 0 1 3}$ & $\mathbf{2 0 1 2}$ & $\begin{array}{c}\text { \% Increase } \\
\text { (Decrease) }\end{array}$ & Remark \\
\hline $\begin{array}{l}\text { Inventory turnover } \\
\text { ratio }\end{array}$ & 21,88 & 18,15 & $21 \%$ & $\mathrm{Up}$ \\
$\begin{array}{l}\text { Day`s inventory } \\
\text { Account receivable }\end{array}$ & 16,45 & 19,84 & $-17 \%$ & Down \\
turnover ratio & 3,35 & 3,14 & $7 \%$ & $\mathrm{Up}$ \\
Day`s receivable & 107,34 & 114,49 & $-6 \%$ & Down \\
\hline
\end{tabular}

If it is carefully analyzed, the result presented in Table 4 shows that the inventory turnover ratio has increased from 18.15 to 21.88 or up $21 \%$. This result indicates that in a period of one year, the medical inventories of the hospital have turned 21 times. This high number of inventory turnover ratio has certainly indicated that the day's inventory is shorter. This condition has been proven by the decreasing number of day's inventory from 19.84 to 16.45 or down $17 \%$.

From the same table, the result of account receivable turnover ratio has indicated an improvement from 3.14 to 3.35 or up $7 \%$. This result indicates that in period of one year the account receivable has turned three times. In term of day's receivable, it has also shown favorable condition by the decreasing number of days from 114.49 to 107.34 or down $6 \%$. However, due to its higher number of days above normal 90 days for hospital practices, this figure has certainly urged to be overcome. That's why, the owner of the hospital still needs to invest fund in this hospital as previous analyzed.

Table 5 presents the result of long-term solvency ratio calculation as depicted below.

Table 5 Long-Term Solvency Ratio

\begin{tabular}{ccccc}
\hline \multicolumn{1}{c}{ Ratio } & $\mathbf{2 0 1 3}$ & $\mathbf{2 0 1 2}$ & $\begin{array}{c}\text { \% Increase } \\
\text { (Decrease) }\end{array}$ & Remark \\
\hline $\begin{array}{l}\text { Total debt ratio } \\
\begin{array}{l}\text { Debt to equity } \\
\text { ratio }\end{array}\end{array}$ & 0,73 & 0,75 & $-2 \%$ & Down \\
\hline
\end{tabular}


From Table 5, it shows an improvement of the total debt ratio from 0.75 to 0.73 or decreased by $2 \%$. This result indicates that the dependency of the hospital on debt as its source of fund has decreased. This can be understood by the funding from owner to strengthen its financial position. From debt to equity side, it shows that the ratio has been decreased from 2.97 to 2.74 or decreased by $8 \%$. This also shows that there is an improvement on the hospital's margin of safety for its creditors.

Table 6 is to depict the result of profitability ratio calculation.

Table 6 Profitability Ratio

\begin{tabular}{ccccc}
\hline \multicolumn{1}{c}{ Ratio } & $\mathbf{2 0 1 3}$ & $\mathbf{2 0 1 2}$ & $\begin{array}{c}\text { \% Increase } \\
\text { (Decrease) }\end{array}$ & Remark \\
\hline Return on Assets & 0,15 & 0,14 & $7 \%$ & $\mathrm{Up}$ \\
Return on Equity & 0,58 & 0,56 & $4 \%$ & $\mathrm{Up}$ \\
\hline
\end{tabular}

From Table 6, it can be seen that there are two ratios calculated. The first one is return on assets. The result shows that there is an improvement from 0.14 to 0.15 or increased by $7 \%$. This indicated that $15 \%$ of the hospital revenue is achieved from asset utilization. Second, return on equity. This result also indicates a favorable one from 0.56 to 0.58 or increased by $4 \%$. This shows that about half of the revenue of the hospital is resulted from benefiting of equity invested by the owner.

\section{CONCLUSIONS}

As an overall result, financial statement analysis shows an improvement in financial performance of ABC Hospital. However, there is a significant change of dependency from debt to equity. Therefore, based on this result, ABS Hospital is stated to have better financial management conduct and for this effort, the government has approved its fulfillment of the quality of administrative service standard related on financial performance to ensure its sustainable healthcare service for Indonesia society.

\section{REFERENCES}

Florenz, C. T. (2012). A Comparative Analysis of the Financial Ratios of the Financial Ratios of Listed Firms Belonging to the Education Subsector in the Philippines of the Years 2009-2011. International Journal of Business and Social Science, 3(21), 173190.

Garrison, R. H. (2012). Managerial Accounting an Asian Perspective. $1^{\text {st }}$ Edition. Singapore: McGraw-Hill.

Haka, W. (2010). Financial and Managerial Accounting: The Basis for Business Decision (15 ${ }^{\text {th }}$ ed.). New York: McGraw-Hill.

Komite Akreditasi Rumah Sakit (KARS). (2011). Standar Akreditasi Rumah Sakit. Jakarta: KARS.

Komite Akreditasi Rumah Sakit (KARS). (2011). Pedoman Proses Survei Akreditasi Rumah Sakit. Jakarta: KARS. 